Original Article

\title{
Hubungan Status Hipertiroid dengan Tingkat Depresi Usia Dewasa Tengah di Komunitas Pita Tosca Wilayah DKI Jakarta
}

\author{
Rotua Dinarta Sihombing ${ }^{1}$, Sancka Stella ${ }^{2}$, Lannasari $^{3}$ \\ 1,2,3 Program Studi Ilmu Keperawatan \\ 1,2,3 Sekolah Tinggi Ilmu Kesehatan Indonesia Maju \\ Jl.Harapan nomor 50, Lenteng Agung-Jakarta Selatan 12610 \\ Email: rotua@stikim.ac.id
}

\begin{abstract}
Abstrak
Latar Belakang: Depresi adalah gangguan kejiwaan pada sesorang dengan gejala wajah murung, selalu merasa sedih, merasa tertekan. Hipertiroid merupakan salah satu kondisi dimana aktivitas kelenjar tiroid yang terlalu banyak mensintesis hormon pada tiroid. Akibatnya terjadi peningkatan metabolisme pada jaringan perifer.

Tujuan: Penelitian ini bertujuan untuk mengetahui tentang hubungan status hipertiroid dengan tingkat depresi pada usia dewasa menengah.

Metode: Jenis penelitian ini mengunakan jenis penelitian korelasional yang mengidentifikasi hubungan antara kejadian hipertiroid dengan kejadian depresi di komunitas pita tossca wilayah DKI jakarta.

Hasil: Hasil dari penelitian ini menunjukan bahwa seluruh responden yang mengalami hipertiroid berjenis kelamin wanita yaitu sebanyak $97.3 \%$. Status perkawinan dan status pekerjaan tidak mempunyai hubungan statistik terhadap kejadian hipertiroid. Responden dengan kadar tiroid lebih dari normal (hipertiroid) hampir setengah mengalami depresi sedang yaitu dengan presentase 40,5\%.

Kesimpulan: Dari penelitian ini dapat disimpulkan bahwa ada hubungan status hipertiroid dengan tingkat depresi usia dewasa menengah di komunitas Pita Tosca wilayah DKI Jakarta Tahun 2021 yaitu dengan p-value $=0,030$.

Kata Kunci: depresi, dewasa tengah, hipertiroid.

Editor: Wk

Hak Cipta:

(C)2021 Artikel ini memiliki akses terbuka dan dapat didistribusikan berdasarkan ketentuan Lisensi Atribusi Creative Commons, yang memungkinkan penggunaan, distribusi, dan reproduksi yang tidak dibatasi dalam media apa pun, asalkan nama penulis dan sumber asli disertakan. Karya ini dilisensikan di bawah Lisensi Creative Commons Attribution Share Alike 4.0 Internasional.
\end{abstract}




\section{Pendahuluan}

Pada zaman yang sangat maju ini, banyak populasi manusia yang mengalami rasa stress dan cemas, bahkan depresi. ${ }^{1}$ Gejala ini merupakan salah satu tanda awal dari penurunan kondisi kesehatan seseorang, dimana ketika seseorang mengalami gejala, cemas dan depresi yang berlarut larut dan tidak diobati maka akan dapat mengakibatkan lemahnya sistem pertahanan tubuh sehingga tubuh akan rentan terserang penyakit penyakit mematikan seperti hipertensi, gangguan jantung, kanker dan lain-lain.

Pada penelitian yang diadakan di Amerika bahwa ketika mereka datang dengan keluhan sariawan, susah tidur, diabetes dan gangguan pernapasan maka sekitar 28 orang dari 32 orang yang diteliti sebelum terdampak suatu penyakit, maka didapati mereka mengalami gangguan stress, cemas, bahkan depresi. Hal ini dapat terjadi karena coping diri yang kurang dalam mengatasi suatu persoalan dalam hidup. ${ }^{1}$ Prevalensi penderita depresi sejak tahun 2005 hingga tahun 2017 dikatakan oleh WHO mengalami lonjakan sebesar 18\%. Prevalensi di Indonesia didapati sekitar 3,7\% dari 250 juta penduduk, dan hanya $8 \%$ yang mendapatkan pelayanan yang tepat, sebesar $92 \%$ tidak mendapatkan penanganan yang baik. Dari total data penderita depresi tersebut hanya $8 \%$ yang dapat terlayani, sedangkan sisanya sebanyak $92 \%$ tidak mendapatkan pelayanan yang tepat. ${ }^{2}$ Pada tahun 2017, WHO merilis bahwa banyak sekali percobaan bunuh diri setiap tahunnya, ditemukan sekitar 800.000 uji coba bunuh diri. Pada tahun 2013 Kesehatan Dasar melakukan riset terhadap manusia dengan umur 15 tahun keatas, sekitar 6\% atau 14 juta jiwa mengalami gangguan mental dengan gejala kecemasan dan depresi. $^{3}$

Depresi adalah gangguan kejiwaan pada sesorang dengan gejala wajah murung, selalu merasa sedih, merasa tertekan, mengalami suasana hati yang naik turun dan adapula gejala anxious stress atau yang dikenal dengan tekanan kecemasan. Penderita yang mengalami depresi akan mengalami perasaan yang bimbang, selalu merasa waswas, tidak dapat fokus karena merasakan kegelisahan atau kekhawatiran yang berkepanjangan, Diagnosa depresi dapat ditegakkan apabila sesorang mengalami perasaan sedih, tidak memiliki harapan dan merasa tidak berharga selama 2 minggu bahkan lebih. ${ }^{1}$ Dampak dari depresi adalah seseorang itu selalu merasa kesepian, tidak memiliki harapan dan keinginan untuk melakukan sesuatu dengan baik, tidak dapat tidur dan akibatnya seseorang itu akan menunjukkan perasaan yang sangat sensitif seperti mudah tersinggung, rasa sedih terus menerus, dan pola makan yang tidak teratur. ${ }^{1}$ Depresi mempunyai beberapa tingkatan, yaitu depresi ringan, depresi sedang dan depresi berat, dimana ciri ciri dengan depresi ringan adalah kehilangan minat, cepat lelah, aktivitas terganggu, sulit berkonsentrasi, tidak dapat melakukan aktivitas sosial yang dapat berlangsung selama 14 hari, depresi sedang memiliki ciri kurangnya kepercayaan diri, selalu merasa bersalah, sulit tidur ,dan tidak memiliki gambaran atau pandangan mengenai masa depan. Depresi berat mempunyai gejala klinis lebih parah, adanya kecenderungan melakukan aktivitas bunuh diri, halusinasi dan waham. ${ }^{3}$

Kelenjar tiroid merupakan kelenjar endokrin dalam tubuh, mempunyai fungsi utama untuk mensekresi hormon tiroid yang berguna untuk mempertahankan tingkat metabolisme di semua jaringan supaya dapat berfungsi dengan maksimal serta mensekresi hormon kalsitonin yang berfungsi mengatur kadar kalsium dalam darah. ${ }^{4}$ Tiroid menghasilkan dua jenis hormon utama, yaitu hormon tiroksin (T4) dan hormon triiodotironin (T3). Kedua hormon sangat berperan dalam peningkatkan kecepatan metabolisme tubuh. ${ }^{5}$ 
Ada beberapa gangguan pada kelenjar tiroid, salah satunya adalah hipertiroid. Hipertiroid merupakan salah satu kondisi dimana aktivitas kelenjar tiroid yang terlalu banyak mensintesis hormon pada tiroid. Akibatnya terjadi peningkatan metabolisme pada jaringan perifer. Hipertiroid dikatakan memiliki risiko terhadap kesehatan jantung dan juga tulang, peningkatan risiko demensia dan Alzheimer yaitu penyakit degeneratif yang sering menyerang lansia. ${ }^{6}$ Prevalensi keseluruhan penderita hipertiroid di Amerika Serikat adalah 1,2\%, dan di negara bagian Eropa 0,8\%.7 Menurut Indonesian Basic Health Research Data, 2007 hipertiroid di Indonesia adalah 6,9\% dan di Jakarta 0,7\% dan pada tahun 2015, Indonesia menempati posisi tertinggi penderita gangguan tiroid di wilayah Asia Tenggara. Dan apabila dijumlahkan sesuai riset IMS health ditemukan sekitar 17 juta penduduk Indonesia mengalami gangguan tiroid. ${ }^{8}$

Adapun tanda dan gejala dari kelebihan konsentrasi hormon tiroid meliputi turunnya berat badan secara drastis, tidak tahan terhadap suhu panas, kelemahan pada otot, sering buang air besar, reflek hiperaktif, tangan bergetar, gugup, sulit tidur dan kecemasan. Ada juga gejala tremor, mata seperti menonjol dan adanya pembengkakan pada leher, terutama apabila disebabkan oleh penyakit Graves. Denyut jantung yang tidak beraturan adalah presentasi hipertiroidisme, tetapi tanda-tanda kardiak juga mencakup sinus takikardi dan gagal jantung kongesti, karena jantung dipaksa untuk bekerja lebih berat dan lebih cepat sehingga semakin lama jantung menjadi tidak mampu untuk memompa darah yang cukup sesuai dengan kebutuhan. Sehingga Efek samping dari semua gangguan yang tertera diatas adalah munculnya gejala kecemasan yang dapat berakibat kepada depresi. Diagnosis hipertiroidisme dapat dikonfirmasi dengan uji fungsi kelenjar tiroid abnormal, yaitu melalui pemeriksaan pengambilan darah yang meliputi peningkatan hormon serum Tiroksin (T4) dan serum hormon triiodotironin (T3) serta penurunan kadar hormon penstimulasi hormon tiroid. ${ }^{9}$

Biopharma PT Merck Tbk, menyatakan bahwa sebanyak 18\% perempuan Indonesia mengalami gangguan disfungsi tiroid, lebih besar dibandingkan laki laki yang hanya sebanyak $8 \%$. Sebanyak 65\% dari koresponden yang berjumlah 6000 orang penderita hipertiroid mengatakan bahwa mereka mengalami gangguan cemas bahkan mengarah kepada depresi, sedangkan sebanyak 35\% koresponden tidak menyangkutpautkan depresi atau cemas akibat penyakit hipertiroid. Pengobatan bagi penderita hipertiroid berpusat pada proses menurunkan hormon T3 dan hormon T4, serta mempertahankan kadar TSH dalam batas normal. ${ }^{8}$

Di Indonesia terdapat beberapa komunitas yang menaungi peserta gangguan tiroid, salah satunya adalah Komunitas Pita Tosca, komunitas untuk penyintas kanker tiroid. Komunitas Thiroid Pita Tosca didirikan oleh Astriani Dwi Aryaningtyas pada tahun 2014 dan merupakan wadah penyintas dan pasien kanker tiroid. Komunitas ini banyak membahas tentang gangguan fisik dan psikis karena banyaknya penderita tiroid mengalami cemas, mudah lelah dan depresi. Komunitas Pita Tosca memiliki 814 anggota yang tersebar di Indonesia, 50\% diantaranya adalah penyintas kanker tiroid. Komunitas Thiroid Pita Tosca memiliki agenda rutin yaitu diskusi dan edukasi kesehatan tiroid. Selain itu juga terdapat kegiatan ngobrol santai dengan dokter spesialis pada bidang masalah tiroid.

\section{Metode}

Jenis penelitian ini mengunakan jenis penelitian korelasional. Populasi sebesar 290 orang menggunakan Teknik Simple Random Sampling dengan penentuan jumlah sampel menggunakan rumus slovin, didapatkan sampel sejumlah 74 orang. Penelitian ini mengidentifikasi hubungan antara kejadian hipertiroid dengan kejadian depresi di komunitas 
pita tossca wilayah DKI jakarta. Penelitian ini terdapat dua variabel yaitu variabel independen dan dependen. Variabel Independen yaitu variabel yang mempengaruhi variabel dependen. Variabel independen pada penelitian ini adalah Kejadian Hipertiroid. Sedangkan variabel dependennya adalah Depresi.

Peneitian ini telah lulus uji etik di Komisi Etik Penelitian Kesehatan dengan surat keterangan, nomor: 1085/Sket/KaDept/RE/STIKIM/VI/2020.

Hasil

Tabel 1. Distribusi frekuensi Status Hipertiroid Komunitas Pita Tosca Usia Dewasa Tengah Wilayah DKI Jakarta

\begin{tabular}{lcc}
\hline Status Hipertiroid & Frekuensi & Persentase \\
\hline Normal & 16 & 21,6 \\
Hipertiroid & 58 & 78,4 \\
Total & $\mathbf{7 4}$ & $\mathbf{1 0 0}$ \\
\hline
\end{tabular}

Berdasarkan tabel diatas menunjukkan bahwa hampir seluruh responden memiliki status Hipertiroid $(78,4 \%)$ sebanyak 58 orang.

Tabel 2. Distribusi Frekuensi Tingkat Depresi pada Komunitas Pita Tosa Usia Dewasa Menengah Wilayah DKI Jakarta

\begin{tabular}{lcc}
\hline Tingkat Depresi & Frekuensi & Persentase \\
\hline Tidak Depresi (Normal) & 18 & 24,3 \\
Depresi Ringan & 6 & 8,1 \\
Depresi Sedang & 30 & 40,5 \\
Depresi Parah & 11 & 14,9 \\
Depresi Sangat Parah & 9 & 12,2 \\
Total & 74 & 100 \\
\hline
\end{tabular}

Berdasarkan table di atas menunjukkan bahwa hampir setengah responden mengalami depresi sedang $(40,5 \%)$.

Tabel 3. Hubungan Status Hipertiroid dengan Tingkat Depresi pada Komunitas Pita Tosca Usia Dewasa Menengah Wilayah DKI Jakarta

\begin{tabular}{|c|c|c|c|c|c|c|c|c|c|c|c|c|c|}
\hline \multirow{3}{*}{$\begin{array}{l}\text { Status } \\
\text { Hipertiroid }\end{array}$} & \multicolumn{10}{|c|}{ Tingkat Depresi } & & & \multirow{3}{*}{$\begin{array}{l}\mathrm{P}- \\
\text { Value }\end{array}$} \\
\hline & \multicolumn{2}{|c|}{$\begin{array}{l}\text { Tidak } \\
\text { depresi } \\
\text { (Normal ) }\end{array}$} & \multicolumn{2}{|c|}{$\begin{array}{l}\text { Depresi } \\
\text { Ringan }\end{array}$} & \multicolumn{2}{|c|}{$\begin{array}{l}\text { Depresi } \\
\text { Sedang }\end{array}$} & \multicolumn{2}{|c|}{$\begin{array}{l}\text { Depresi } \\
\text { Parah }\end{array}$} & \multicolumn{2}{|c|}{$\begin{array}{l}\text { Depresi } \\
\text { Sangat } \\
\text { Parah }\end{array}$} & \multicolumn{2}{|c|}{ Total } & \\
\hline & $\mathrm{N}$ & $\%$ & $\mathrm{~N}$ & $\%$ & $\mathrm{~N}$ & $\%$ & $\mathrm{~N}$ & $\%$ & $\mathrm{~N}$ & $\%$ & $\mathrm{~N}$ & $\%$ & \\
\hline Normal & 9 & 12,2 & 1 & 1,4 & 3 & 4,05 & 2 & 2,7 & 1 & 1,35 & 16 & 21,6 & \\
\hline Hipertiroid & 9 & 12,2 & 5 & 6,8 & 27 & 36,5 & 9 & 12,2 & 8 & 10,8 & 58 & 78,4 & \\
\hline Total & 18 & 24,3 & 6 & 8,1 & 30 & 40,5 & 11 & 14,9 & 9 & 12,2 & 74 & 100 & 0,02 \\
\hline
\end{tabular}

\section{Pembahasan}

\section{Data Demografi}

Penelitian ini mendapatkan hasil mengenai data karakteristik responden berupa jenis kelamin, status pendidikan, status perkawinan dan status pekerjaan. Jenis kelamin responden sebagian besar yaitu wanita dengan jumlah 67 responden (90, 5\%). Sedangkan responden yang berjenis kelamin laki-laki berjumlah 7 responden dengan presentase $(9,5 \%)$. Hal ini sejalan dengan hasil penelitiannya Sari et al bahwa hipertiroid lebih banyak terjadi pada wanita dikarenakan wanita memiliki hormon estrogen yang lebih banyak daripada laki-laki sehingga hormon estrogen menyebabkan hormon tiroid tidak dapat bekerja secara maksimal. ${ }^{10}$ 
Hasil penelitian ini menunjukkan bahwa hipertiroid banyak terjadi pada wanita dan kasus tersebut akan meningkat seiring penambahan usia pada seorang wanita. Perbandingan kejadian hipertiroid antara wanita dengan laki-laki yaitu 8:1. Kasus hipertiroid dapat terjadi di pada semua usia namun sebagian besar kasus ini terjadi pada usia diantara 40-60 tahun. ${ }^{11}$

Hasil penelitian ini sesuai dengan penelitian yang dilakukan di negara lain. Di negara Inggris kasus hipertiroid terjadi pada $2 \%$ wanita. Kasus tersebut 10 kali lipat dibandingkan dengan kasus hipertiroid pada laki-laki. Kasus yang sama di Amerika ditemukan bahwa prevalensi keselurhan hipertiroid yaitu 1,2\%. Hipertiroid akan meningkat seiring bertambahnya usia dan cenderung menyerang wanita. ${ }^{12}$

Hasil penelitian ini juga sejalan dengan penelitian yang dilakukan Munifa tahun 2011 yang menyebutkan bahwa resiko tinggi hipertiroid dialami oleh kelompok usia dewasa yaitu rata-rata kisaran 30-50 tahun dimana usia 40 tahun paling beresiko. Di sisi lain penelitian lain yang dilakukan Aga Pratama dkk mendapatkan hasil bahwa prevalensi hipertiroid pada wanita ditemukan sebanyak $41.73 \%$ dalam rentang usia 21-30 tahun. ${ }^{13}$

Variabel lain yang diteliti dan diperkirakan terdapat hubungan dengan fungsi tiroid mencakup status perkawinan, status pekerjaan dan pendidikan. Variabel status perkawinan dan status pekerjaan tidak mempunyai hubungan statistik terhadap kejadian hipertiroid. Sedangkan tingkat pendidikan responden berhubungan dengan kejadin hipertiroid. Responden yang tingkat pendidikannya lebih tinggi (perguruan tinggi) mempunyai proporsi kejadian hipertiroid lebih tinggi dibandingkan responden yang tingkat pendidikannya SMA. Hasil penelitian ini sejalan dengan penelitian yang telah dilakukan oleh Diah Yunitawati mengenai kecemasan dan gangguan fungsi tiroid pada wanita usia subur. Penelitian tersebut mendapatkan hasil bahwa status perkawinan serta pekerjaan tidak berhubungan dengan fungsi tiroid. ${ }^{6}$

\section{Status Hipertyroid dan Status Depresi}

Hasil penelitian ini menunjukkan bahwa sebagian besar responden mempunyai kadar tiroid lebih dari normal (hipertiroid). Kadar tiroid yang lebih dari normal dapat menyebabkan perubahan mood dan gangguan kecemasan. Gangguan psikiatrik yang muncul pada seseorang yang mempunyai gangguan tiroid dapat berupa kecemasan, panik serta depresi. ${ }^{14}$

Ada beberapa tingkatan depresi yang dialami oleh responden penelitian ini mulai dari tidak depresi hingga depresi parah. Akan tetapi sebagian besar responden banyak yang mengalami depresi ringan dan depresi sedang yaitu sebanyak 30 dan 36 responden. Penelitian klinis sudah mengenali adanya hubungan tiroid dengan depresi. ${ }^{6}$ Pasien dengan hipertiroid mengalami gejala neuropsikiatri yang lebih luas termasuk kecemasan dan depresi. Ganguan hipertiroid dapat disertai dengan berbagai manifestasi klinis neuropsikiatri mulai dari depresi ringan dan kecemasan. ${ }^{15}$

Subjek penelitian ini merupakan penyintas dan pasien kanker tiroid di Komunitas Pita Tosca yang masuk usia dewasa tengah. Responden yang ada di komunitas ini berkumpul untuk berdisuksi tidak hanya keluhan secara fisik tetapi juga kecemasan hingga depresi yang dialami. Hasil penelitian menunjukkan bahwa sebagian besar responden mengalami hipertiroid.

Analisis terhadap tingkat depresi responden didapatkan hasil bahwa sebagian besar responden yang mempunyai hipertiroid mengalami depresi ringan dan depresi sedang. Selain itu, terdapat responden yang kadar tiroidnya lebih dari normal yang mengalami depresi parah. Sedangkan, responden yang kadar tiroidnya lebih dari normal dan tidak mempunyai masalah 
secara psikologis jumlahnya hanya sedikit. Kondisi ini menunjukkan bahwa sebenarnya depresi menjadi masalah yang dihadapi pasien di Komunitas Pita Tosca.

\section{Kesimpulan}

Berdasarkan hasil penelitian yang telah dilakukan yaitu Hubungan Status Hipertiroid dengan Tingkat Depresi Usia Dewasa Tengah di Komunitas Pita Tosca Wilayah DKI Jakarta Tahun 2021 pada 74 responden maka dapat disimpulkan bahwa: hampir seluruh responden yang mengalami hipertiroid berjenis kelamin wanita yaitu sebanyak 97.3\%. Status perkawinan dan status pekerjaan tidak mempunyai hubungan statistik terhadap kejadian hipertiroid. Responden dengan kadar tiroid lebih dari normal (hipertiroid) hampir setengah mengalami depresi sedang yaitu dengan persentase $40,5 \%$. Ada hubungan status hipertiroid dengan tingkat depresi usia dewasa menengah di komunitas Pita Tosca wilayah DKI Jakarta Tahun 2021 yaitu dengan $p$-value $=0,030$.

\section{Konflik Kepentingan}

Peneliti menyatakan bahwa penelitian ini independen dari konflik kepentingan individu dan organisasi.

\section{Ucapan Terima Kasih}

Terimakasih kepada seluruh pihak yang telah berkontribusi membantu proses penelitian ini.

\section{Pendanaan}

Sumber pendanaan diperoleh dari peneliti.

\section{Daftar Pustaka}

1. Dirgayunita A. Depresi: Ciri, Penyebab dan Penangannya. J An- Nafs Kaji Dan Penelit Psikol. $2016 ; 1: 1$.

2. Sari I. Faktor-Faktor yang Berhubungan dengan Depresi pada Pasien Diabetes Mellitus Tipe-2 di Grha Diabetika Surakarta. 2016;

3. Sulistyorini W, Sabarisman M. Depresi: Suatu Tinjauan Psikologis Sosio Informa. 2017;1:1.

4. Barret K, Barman S, Boitano S, Brooks H. Ganong's Review of Medical Physiology: Thyroid Glands, 24th ed. United State America: The McGrawhill Companies; 2014.

5. Halverson J. Depression. 2013;

6. Yunitawati D, Latifah L. . (2017). Kecemasan dan Gangguan Fungsi Tiroid pada Wanita Usia Subur. MGMI, 7(2), 107-116. MGMI. 2017;7(2):107-16.

7. Srikandi P. Hipertiroidismee Graves Disease:Case Report. J Kedokt RAFLESIA. 2020;6(1):30-5.

8. Syuhada, Rafie R. Korelasi Kadar Tiroksin (T4), Triiodotironin (T3) dan Thyroid. 2015;

9. Syahrul M, Jasmine N. Tata Laksana Anestesi pada Sectio Caesar Pasien G4P3A0H3 gravid aterm 3839 minggu dengan Hipertiroid. J Kesehat Andalas. 2019;8(1).

10. Sari EE, Susanto HS, Udiyono A, Suwandono A. Beberapa Faktor Risiko Kejadian Hipertiroid pada Wanita Usia Subur di Kabupaten Magelang "Studi Kasus di Klinik Litbang Bp2gaki Magelang." J Kesehat Masy. 2017;3(3):152-61.

11. Raflesia. Hipertiroidismee Graves Disease: Case Report. J Kedokt RAFLESIA. 6(1):30-5.

12. Camacho P., Gharib H. Evidencebase Endocrinology. In: 2nd ed. Philadelphia: Lippincot Williams \& Wilkins; 2007.

13. Munifa. Pola Makan dan Merokok Sebagai Faktor Risiko Kejadian Hipertiroid. 2011;

14. Victoria, Hendrick, Thomas. Psychological factors affecting medical conditions. In: Sadock BJ, Sadock VA, editors. Comprehensive Textbook of Psychiatry. Philadelphia: Lipincott William \& Wilkins Publishers; 2000.

15. Hage M., Azar ST. Review Article The Link between Thyroid Function and Depression. Hindawi Publ Corp J Thyroid Res. 2012; 